\title{
Conceptual Metaphors in The Daily Show with Jon
}

Stewart $\left.^{*}\right)$

\author{
Under the Supervision of \\ Dr. Amira Agameya
}

\author{
Submitted by \\ Iman Mohamed Essam Saifalnasr Baza \\ Ph.D. Candidate English Department \\ Faculty of Arts- University of Cairo
}

\begin{abstract}
In this paper, the researcher studied Conceptual Metaphors and how they were used in an American satirical show. The researcher specifically looked at episodes from The Daily Show with Jon Stewart in April, May and June, 2013. A mixed-design approach was used to decide on the kinds of conceptual metaphors used. The researcher mainly used a qualitative approach to decide on the emerging patterns of Conceptual Metaphors, based on George Lakoff and Mark Johnson's (1980) book Metaphors We Live By, and then used frequency counts to decide on the most common kinds. The analysis showed that structural metaphors were more common than ontological metaphors with POLITICS AS ART and GOVERNEMNT AS A CORRUPT BUSINESS MODEL being the most used (59\%). This showed that the use of some source domains like art and business rendered the message clear to the audience in terms of who their presidents and politicians really were. As for ontological metaphors, personification was mostly used, especially when talking about the GOVERNMENT AS A HYPOCRITE AND LIAR and JOURNALISM AND
\end{abstract}

(*) Conceptual Metaphors in The Daily Show with Jon Stewart, Vol.10, Issue No.3, July 2021, pp.37-59. 
PROSECUTION AS FREE HUMAN BEINGS. Giving a non-living thing a human trait showed the intensity of the message.

\section{Keywords}

media discourse, political discourse, political satire, conceptual metaphors, The Daily Show with Jon Stewart

\section{الملخص}

في هذه الورقة البحثية، قام الباحث بدراسة كيفية استخدام الاستعار ات الإدراكية في برنامج أمريكي للهجاء السياسي ودرس الباحث على وجه الخصوص حلقات من أبريل ومايو

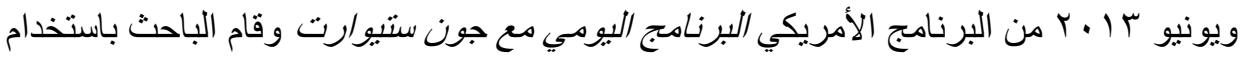

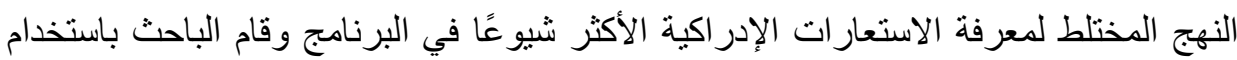

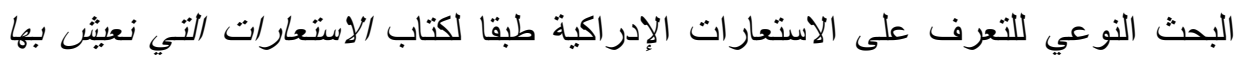

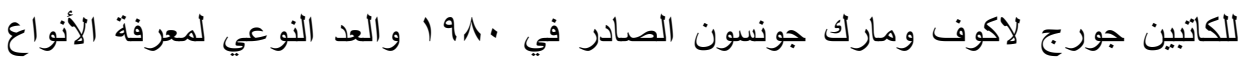

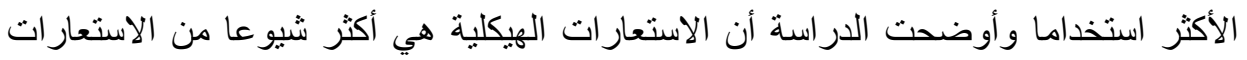

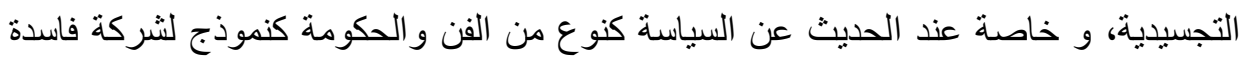
وبالنسبة للاستعار ات التجسيدية فتمثل في الحكومة كثخص كاذب ومنافق و الصحافة و القضاء كأناس بتمتعون بالحرية.

الكلمات المفتاحية

الخطاب الإعلامي، الخطاب السياسي، الهجاء السياسي، الاستعار ات الإدراكية، البرنامج

$$
\text { اليومي مع جون ستيو ارت }
$$

Political satire is an area that started to get a lot of attention in recent years, especially with the success of many satirical television shows that gained a lot of fame. One of these shows is The Daily Show with Jon Stewart which criticized the status quo in the American society on the political, economic and social levels. In this paper, the researcher mainly analyzed a number of episodes to answer the following question:

-What are the structural and ontological metaphors used in The Daily Show with Jon Stewart? The researcher used a mixed-design approach 
when looking at the data which was mainly based on a deductive approach to identify the conceptual metaphors using the basic kinds of the Conceptual Metaphor Theory (CMT) in the discourse. The data chosen from The Daily Show with Jon Stewart was from different episodes starting from April, 2013 to June, 2013 and have a total of 115.9 minutes.

\section{Satire on Television}

In the last thirty years, the presence of very successful political comedy shows, such as Politically Incorrect, The Colbert Report, The Daily Show with Jon Stewart and Saturday Night Live, attracted a lot of audience who enjoy the comic content and at the same time use these programs as a source of information on political developments. Pew Research Center, for example, conducted a survey in 2004 asking people about their sources of news (using The Daily Show and Saturday Night Live as examples) and concluded that $21 \%$ of the young generation (aged 18-29) regularly depend on comedy shows, like Saturday Night Live, for news about politics. Another 13\% learn about the news from late-night talk shows, such as Late Show with David Letterman and Tonight Show with Jay Leno (Baym, 2005; Cutbirth, 2011).

Political comedy shows in the United States started to gain a lot of popularity because of their clear embodiment of "freedom of expression", even if it is against presidents and other prominent political figures, the fact that has helped the United States be a pioneer and a role model in democracy and in protecting Article 19 of the Universal Declaration of Human Rights. Satire on TV is not only successful in the States as it has for long been presented in other countries as well. In Canada, TV shows like This hour has 22 minutes, Rick Mercer's Report and Hockey Night in Canada have gained considerable popularity. Similarly, in the UK, programs like That Was the Week That Was (in the 1960s), Spitting Image (in the 1980s), The Day Today and Brass Eye (in the 1990s), Sacha Baron Cohen's famous characters of Ali G and Borat, and Have I 
got News For You are all examples of successful satirical shows (Gray, Jones \& Thompson, 2009).

\section{Conceptual Metaphor Theory (CMT)}

Conceptual metaphors started to be used for analysis in different studies because of how it introduced the concept that it was part of human thought. A metaphor was not regarded as a purely linguistic aspect but rather a "mode of conceptual representation" (McGlone, 2007). It was first introduced in the book Metaphors We Live By by George Lakoff and Mark Johnson (1980). In their book, they gave evidence as to how the use of metaphors in language is deeply rooted in human thought. They believed "that most of our conceptual system[s] are metaphorical in nature" (p.4). The first kind of conceptual metaphors is the structural metaphors, which mean that one understands a concept in terms of another. One concept discussed in the book is the ARGUMENT AS WAR concept. In so many instances, we talk about arguments in terms of attacking, winning or losing. For example, one could say "He attacked every weak point in my argument" or "His criticism was right on target" (p.4). This reflects how this concept is deeply engrained in our minds and it is shaped by our own cultures. That is because we consider arguments to be battles where one has to win or lose. Another concept is "TIME IS MONEY", "TIME IS A LIMITED RESOURCE” or "TIME IS A VALUABLE COMMODITY" (p.8). One could then explain why certain verbs are used for each of these concepts. For example, "spend", "invest" and "cost" could be used for TIME IS MONEY, "use" and "run out of" could be used for "TIME IS A LIMITED RESOURCE" and "give", "lose" and "thank you for" for "TIME IS A VALUABLE COMMODITY". Thus, so one could say, "Is that worth your while?", "Do you have much time left?" or "You don't use your time profitably" (p.8). Another kind is orientational metaphors where concepts are organized in relation to one another. Most of them make use of spatial 
orientation, so they use "up-down", front-back", "in-out" and "on-off" (p. 14). To clarify, HAPPINESS IS UP and SADNESS IS DOWN, so we say expressions like "I'm feeling up" and "That boosted my spirit" or "I'm feeling down" (p.15). This actually goes well with the physical position of the body because being erect is associated with happiness and leaning forward is sadness. Another example is HEALTH AND LIFE ARE UP; SICKNESS AND DEATH ARE DOWN. Hence, we say "he's in top shape" and "he fell ill" (p.15). Another example is HIGH STATUS IS UP; LOW STATUS IS DOWN. Thus, we say "he has a lofty position" and "she fell in status" (p.16). The third kind of metaphor is the ontological metaphor, which means understanding one abstract concept in terms of another concrete one. An example given in the book is INFLATION AS ENTITY (p. 26). For example, one can say, "Inflation is lowering our standard of living" (p.26). Thus, ontological metaphors help in quantifying, referring, identifying causes, identifying aspects, and setting goals and motivating actions. To clarify, one can say, "It will take a lot of patience to finish this book", "My fear of insects is driving my wife crazy", "He did it out of anger", "The ugly side of his personality comes out under pressure", and "He went to New York to seek fame and fortune" (p.26-27) as examples of these metaphors respectively. It is worth mentioning that some famous expressions are actually considered examples of ontological metaphors. To illustrate, THE MIND IS AN ENTITY makes us think that THE MIND IS A MACHINE and THE MIND IS A BRITTLE OBJECT. This could be made clear in "I am $a$ little rusty today" (p.27) and "she is easily crushed" (p.28) respectively.

Another important clarification made in the book is the container metaphors. For example, VISUAL FIELDS ARE CONTAINERS as in "The ship is coming into view" (p. 30). Similarly, one can talk about a race as a container object in "Are you in the race on Sunday?" (p.31). Besides, any activity can be viewed as a substance and hence a container: "How did you get into window washing as a profession?" (p.31). This means that activities are considered as containers for any activity or 
action that help in making it. A lot of other expressions are also viewed as containers like "He's in love" and "We're out of trouble now" (p.32). Another clear example of ontological metaphors is personification, where a non-human object is given a human characteristic. For example, "His theory explained to me the behavior of chickens raised in factories" (p.33). The theory here is like a person who has the capability to explain. Metaphors are also related to culture and they share the same values. For example, in the UP-DOWN metaphors, it is believed that "More is better" and not "Less is better", which is similar to GOOD IS UP (p.18).

\section{CMT: Support and Criticism}

A lot of debate surrounded the validity of this theory. For example, one of the most debated topics in the congressional elections of 2006 was what Bush meant by "stay the course" when talking about Americans staying in Iraq. For a lot of people, it meant not changing their plans, but for a lot others, it was part of a journey that was started by the American administration and the destination would be reached when Iraq has the basis of democracy (Gibbs, 2011).

Despite the possible ambiguity, there are a lot of claims that support CMT; to clarify, there a lot of concepts that are present in many metaphors, two of which are talking about "love as a journey" and "love as a natural force". Besides, most of the polysemous words are structured by some cognitive principles that underlie CMT (Gibbs, 2011). For example, the relationship between the word "see" as "understand" indicates the concept of "understanding is seeing". The possibility of tracking "dead metaphors" or an unconventional expression to a concept renders the validity of the theory. For example, "stay the course", as mentioned above, could be explained in terms of "being in a journey that has to be completed". Another claim to support the theory is that a lot of the novel metaphorical expressions are creative instances of some metaphors, such as using the concept of "journey" to express something about love. For example, "My marriage is a roller coaster" describes love 
as a physical journey (Gibbs, 2011). A lot of studies have also been conducted and proved that a lot of conceptual domains like emotions, politics, mathematics, illness and legal domains do exist.

Despite these claims, some scholars identified some flaws with the theory, one of which is that there is no clear model or format that is used by scholars to reach their conclusions (Gibbs 2011; McGlone, 2007). For example, there is no clear distinction of what makes a metaphor, the criteria of systematicity among some linguistic expressions that could refer to the same target domain, or criteria for choosing one metaphorical concept and not the other. The real criteria of how representative the analyses scholars make of the real life discourse and what speakers actually meant are not clear. This means that understanding concepts might not necessarily be a recognition process of what a certain expression means; it could actually be explained in terms of the "attributive categorization" discourse model (Glucksberg et al., 1997, McGlone, 1996, McGlone and Manfredi, 2001, as cited in McGlone, 2007). Thus, the expression "our marriage is a roller coaster" could be explained in terms of having a ride i.e. roller-coaster which could be a happy or scary ride and "marriage" could be a member of such a ride as is the case with other topics that could have the same attributes of the ride like careers, adolescence, etc. (McGlone, 2007).

Another claim is that not all conventional expressions could necessarily be explained in terms of CMT. Besides, the theory never explained how some inflectional changes in one word, i.e. singular or plural, could account for the difference in meaning. To clarify, the word "flames" denote a negative meaning in "his future crashed in flames", while "George still carried a flame for Kelly" has a more positive meaning (Gibbs, 2011).

Another noteworthy criticism is the basis on which Lakoff and Johnson (1980) built their claim. They believed that all abstract concepts stem from concrete concepts and that is why there are parallel 
representations (McGlone, 2007). However, if this claim were true, then how could one account for some literal meanings? The example given was that of building. If one assumes that knowledge of theories is a subset of building knowledge, then all theories are not metaphoric but actually literal ones, which does not accurately describe the conceptual thought of humans (McGlone, 2007).

Kovecses (2010) wrote about the universality of metaphors and that in so many cases they are universal or near-universal. This universality is explained in terms of either by chance all languages developed the same metaphors or they borrowed metaphors from each other. Another explanation is that there is some universal basis for these metaphors to develop in the same way. This could be because the experiences people have are the same. For example, in the metaphor HAPPINESS IS UP, most people associate it with positive and upward feelings and that explains why it is found in English, Chinese and Hungarian. However, there are still culture-specific ones. He also pointed out that there are cross cultural metaphors. These metaphors may agree that THE ANGRY PERSON IS A PRESSURIZED CONTAINER (p.207), but the nature of the container or the liquid inside, etc. could be different. It was also explained that there are within-culture variations because of the subcultural and social differences (Kovecses, 2010).

\section{Political Discourse and CMT}

Some studies were conducted in order to know the type and frequency of conceptual metaphors used in political discourse. For example, Chen (2014) analyzed Zhejiang provincial government work reports diachronically to see development trends in different periods of time and how the government changed its use of metaphors. These reports were taken from Zhejiang. Results showed that in 30 years, the most used metaphors were war and travel metaphors. The government was seen as the conductor, the people as warriors and the construction of the province as fighting. It was also noted that whenever there was 
instability, war metaphors were used to show a strong stance. Travel metaphors, which always refer to the presence of a destination, were also used to show that the province wanted to reach the state of a rich and modern province. The citizens would be the travelers and the principles of the Party Central Committee would be the guide.

Brugman, Burgers and Vis (2019) worked on a meta-analysis of 91 studies and their results showed that the metaphorical frames were much more persuasive in political discourse than the non-metaphorical frames. In their article, they also referred to Lakoff's book on moral politics and how he proposed two levels of reasoning. These two levels of reasoning were either the government treats the citizens as a strict father, representing strength, or as a nurturing parent who always supports. Renardel de Lavalette et al. (2016, as cited in Brugman et al., 2019) analyzed speeches by Obama and Bush between 2001 and 2010. Using the word-level approach, both presidents used the same numbers of words or expressions denoting the nurturing-parent approach. However, using the concept-level approach, Obama was found to be using more expressions of such kind.

Ohl et al. (2013) used Lakoff's theory of moral reasoning in their comparison of 361 presidential advertisements between the years 1952 and 2012. The two kinds of moral reasoning are the Strict-Father approach and the Nurturant-Parent approach. The former is about politicians believing that they know best, while the latter is about politicians who believe in the power of listening to their people. Results showed that the Republicans used moral reasoning, especially the Strict-father approach, than the Democrats. In addition, Democrats were found to avoid the Nurturant-Parent approach when discussing social programs.

Borčić, Kanižaj and Kršul (2016) analyzed 13.338 words from two interviews with the Croatian president Ivo Josipović in 2009 and 2012. These interviews were both with a weekly show that was broadcast on Croatian television. The results indicated that the most used metaphors were related to reification, personification and POLITICS AS 
JOURNEY/MOVEMENT. As Lesz (2011) indicated, the concept of journey is very important because it shows the public that the politicians work hard and patiently towards reaching their destination.

Semino and Koller (2009) analyzed some speeches and interviews by Italian politicians, namely Emma Bonino and Silvio Berlusconi in order to shed light on the similarities and differences between males and females. The similarities included the use of the same kind of metaphors like MOVEMENT/JOURNEY, WAR and AGRESSION, SPORTS, CONSTRUCTION AND BUIDLINGS, HEALTH and BODY, VISION, SLEEP and DREAM, BUSINESS, and NATURE (p.44). However, the differences were sometimes related to how they used the source domain. For example, in the SPORTS metaphors, Berlusconi used sport in its conventional sense, while Bonino used it in an unconventional way. To clarify, Berlusconi identified himself as a player or a person facilitating difficulties to concentrate on winning, which most people like and identify with. However, Bonino presented herself as a reluctant player because she mainly criticized the Italian politics. In addition, Berlusconi's speech is characterized by male dominance and can at points deal with the emotional side when talking about a feminine topic, while Bonino always used both masculine and feminine roles. She used the masculine source domains of WAR and SPORTS but did so in an unconventional way. She also did not put herself in the center of the talk, unlike Berlusconi, and rather put the issues as the center of the talk and hedged her own opinions.

Charteris-Black (2009) also compared six British male and female members of parliaments in their use of metaphors. There were initially two males (16 and 10 years of experience) and two females (10 years of experience each), but then two more experienced females (24 and 30 years of experience) were added because of the lack of metaphors in the initial data from the first two females. The first four were "candidates for the deputy leadership of the Labour Party" (p.146). The two most experienced females were Labour politicians (p.146). The keywords used 
for the initial search showed the most common ones used in political discourse, which are journeys, light and dark, health and plants (p. 147). The results showed that the male MPs used 53\% metaphors compared to $13 \%$ of less experienced females and $34 \%$ compared to more experienced females. This indicated that males relied on metaphors much more than women and the more experienced females were, the more they used metaphors as well. It is worth mentioning that males used more dark and light metaphors compared to their female counterparts.

Lesz (2011) analyzed twelve speeches given by Obama from 2007 (when he was still a senator) till 2010 (two years after he was elected president). The researcher chose this time frame because Obama was believed to be the most popular during that time and was giving his most important speeches. The themes chosen were related to war, conflicts, terrorism and threats in order to see if there was a certain pattern of conceptual metaphors that he consistently used. The three most used metaphors were Charteris-Black's heroic myth/Lakoff's Fairy Tale of the Just War, journey metaphors as well as construction and destruction metaphors. Obama and his nation were the heroes fighting the bad enemies (like al Qaida). Similarly, Obama was always portrayed as leading his country in a journey towards realizing their goals. He never tried to dehumanize his enemies, but the construction was always on the part of the states and destruction was supposed to be the outcome of war and usually on the part of the villain.

Penninck (2014) analyzed 33 speeches given by four US and three British leaders during the financial crises of 1928 and 2008. The focus of the research was to determine the metaphor density and themes in relation to the US when giving political speeches during these two financial crises. The leaders chosen from the US were Herbert Hoover, Franklin D. Roosevelt, George W. Bush (2005-2009) and Barack Obama. The British leaders were Stanley Baldwin, Gordon Brown and David Cameron. The data analysis showed that density was the highest in 
American speeches compared to the British speeches and was more in Republican leaders with Bush having the highest density. However, both Bush and Obama used more metaphors than before which showed how they had become more common in political speeches. As for the sources used, there were 25 sources for the metaphors, but the most common four types were "battle, machine, construction and journey" (p. 57) followed by "illness, motion and nature" (p.57).

Lemana and Gatcho (2019) analyzed 30 interviews of President Rodrigo Duterte of the Philippines in order to analyze the nature of his political discourse. Among the many features he used were profanity and conceptual metaphors. He used structural and ontological metaphors when talking about "Because oil is everything" (p.107) and that "the word cannot move" (personification). He also used the ontological metaphor of a machine when he talked about "fixing" the problems of the island of Borocay as well as the heroic myths metaphors where the leader was the hero.

\section{Methodology}

The data chosen from The Daily Show with Jon Stewart was from different episodes in April, May, and June, 2013 and had a total of 115.9 minutes. The researcher used a mixed-design approach. The data was first analyzed qualitatively to identify the emerging patterns of conceptual metaphors that were mentioned in Lakoff and Johnson's (1980) book Metaphors We Live By. Frequency counts were then used to decide on the most common kinds of metaphors.

\section{Results and Discussion}

After analysis of the data, certain patterns of both structural and ontological metaphors were identified. The summary of the main findings is made clear in the table below: 


\begin{tabular}{|l|l|}
\hline \multicolumn{1}{|c|}{ Structural Metaphors } & \multicolumn{1}{|c|}{ Ontological Metaphors } \\
\hline Politics As Art & Governemt As A Hypocrite And Liar \\
\hline $\begin{array}{l}\text { Governemnt As A Corrupt } \\
\text { Buisness Model }\end{array}$ & $\begin{array}{l}\text { Journalism And Prosecution As Free } \\
\text { Human Beings }\end{array}$ \\
\hline $\begin{array}{l}\text { Values And Ethics As } \\
\text { Struggles And Challenges }\end{array}$ & \\
\hline Citizens As Objects & \\
\hline $\begin{array}{l}\text { Politicians As Non-Living } \\
\text { Things }\end{array}$ & \\
\hline
\end{tabular}

\section{Structural Metaphors}

There were basically five different kinds of structural metaphors identified in the data: POLITICS AS ART (59\%), GOVERNEMNT AS A CORRUPT BUSINESS MODEL (22.7\%), VALUES AND ETHICS AS STRUGGLES AND CHALLENGES (4.5\%), CITIZENS AS OBJECTS (4.5\%), and POLITICIANS AS NON-LIVING THINGS $(4.5 \%)$.

In POLITICS AS ART, presidents, politicians and party members were compared to fictional characters in movies, cartoons and literature, which rendered the message clear to the audience and evoked laughter. One such reference was made to a correspondent called Rosen, who was accused of leaking the news of North Korea using nuclear tests in 
response to economic sanctions imposed on it. He was then called "character Rosen" to imply that what he did was mere fiction, which was not the case because North Korea was known for its nuclear tests. Stewart also referred to President Obama as a non-fictional character. This was meant to be a reminder that there was, in the real world, a black president to the United States of America, which was not conceived of in the old days. Another reference was made to Dorothy Rabinowitz, from Wall Street Journal editorial board, who claimed that the idea of launching Citi bikes in New York was connected to a "bike lobby" which made Stewart call her Lady Hunger Games in reference to the dystopic novel Hunger Games. This highlighted the stark contrast between those politicians or leaders who were realistic and those who always believed in conspiracy theories against the will of the people. The laughter here was made clear from Stewart's reactions to how much exaggeration and political agenda setting was attributed to the idea of having bikes in a city like New York. In one of the episodes, President Obama was compared to Damian from the movie The Omen. This happened when conservatives were trying to find fault with the president by trying to accuse him for a cover up in relation to the Benghazi attack, where four Americans lost their lives. Even though there was no solid proof against the president, conservatives wanted to accuse him for a cover up for political reasons. Besides, Donald Rumsfeld, former Secretary of Defense, and Dick Cheney, former vice president, were compared to the cartoon characters of Tweedledee and Tweedledum who were famous in the western culture as the characters of a nursery rhyme and in Through the Looking-Glass, What Alice Found There, the sequel to Alice's Adventures in Wonderland. Stewart compared them to those fictional characters in reference to how they preached what they did not do. This was in reference to them both being liars and not being good enough for having told lies to the American public themselves when G.W. Bush was president. So, they accused Obama of lying about the Benghazi attacks for political reasons, while they themselves lied about the 9/11 attacks 
when they were working with Bush.

There was also a reference made to the 1987 movie The Untouchables when nobody from the banking field was prosecuted for the financial crisis of 2008. The word Untouchables did send a message that some people could get away with major crimes just because they had connections.

Another reference was the title of one of the episodes, when talking about the National Rifle Association 142 ${ }^{\text {nd }}$ annual meeting: The Good, the Bad and the Crazy. This reminded people of the movie The Good, the Bad and the Ugly. The reason why Stewart called it such was the difficulty of distinguishing between who was good and who was bad in order to give him a gun. According to Stewart, a person may be good and then become bad and vice versa. Then Stewart commented on how "crazy" it was since certain things were very difficult to discern. There might have been a hidden reference to how "crazy" conservatives were since no one could predict one's motives, whether good or bad, when they wanted to go and buy guns. In the same episode, Stewart made a reference to the movies Star Wars and Star Trek by referring to a conservative as Luke Skywalker from Star Wars and then the Vulcans from Star Trek to show that they, as conservatives, were trying to act like heroes but had a very strange sense of reason. The whole point was to make fun of the idea of not accepting fear, as a tactic, used by Democrats and liberals but still using it on the part of Republicans and conservatives.

Another reference made to the movie Apocalypse was in an episode when Obama appeared in a poster behind Stewart with the name Barackalypse. This was when Stewart was talking about some of the scandals Barack Obama got involved in like the veterans' health records' system that never took place. The name Barackalypse reminds one of the 2007 Apocalypse movie where there was a mother and father looking for their child before an asteroid hit planet earth. The point that Stewart 
wanted to make was that even with Obama, who was believed to be a good president, there were some scandals that nobody could understand why they took place. In that episode, Stewart made it clear that finding data on 900000 veterans to complete the computerized system was not impossible since Obama had the most sophisticated data mining system for his campaign and had volunteers to knock on the doors of 5.2 million houses on one weekend. Thus, if he wanted the system to work, he could have done it.

\section{In GOVERNMENT AS A CORRUPT BUSINESS MODEL,}

Stewart criticized the American government in so many different aspects. The government, represented by the president, secretaries of departments, mayors and officials were like managers or CEOs who were not competent enough to make decisions. These decisions would later have their serious impact on the employees i.e. citizens. One of the decisions that Stewart criticized was implementing the idea of Citi-bikes. Stewart believed that the government did not make a wise decision by having people rent bikes from the streets of New York and paying by credit card. One reason for this was that cyclists did not have enough training and were not obliged to wear helmets. Another reason was that New York was known to have a high crime rate, which meant that those bikes were expected to be stolen; hence, New York was not the best place to start with. Stewart also criticized the Internal Revenue System (IRS) for targeting tea party members, which they later admitted and apologized for. What made the government look worse was when a government official believed that it was well known that the IRS was an independent agency, and thus the government had no right to get involved in their investigations. Stewart believed that the government was still in charge and could at least supervise the process. Thus, the government was like a CEO who was totally adamant about applying some rules, even when it jeopardized the reputation of the whole institution.

Stewart also reminded the audience of Rick Perry, who, during the 2011 presidential debate, forgot one of the three main agencies he wanted 
to eliminate. This showed that even those who were supposed to take over were not competent enough, just like a family business which was being run by people who shared the same qualifications and would never make it better. Another criticism was made against the unprofessionalism of the Office of the Comptroller of the Currency (OCC) and the Mortgage Electronic Registration System (MERS). MERS was supposed to facilitate the process for those who wanted to own a home of their own. However, the system proved to be inefficient. This was made clear when a speaker on TV said the system, which was supposed to help people, was abandoned for not making the procedures easier, which meant that the officials in charge made a quick decision that never proved to be useful. The OCC also failed in their supervision of the whole process.

In the conceptual metaphor of VALUES AND ETHICS AS STRUGGLES AND CHALLENGES, Stewart referred to the forefounders' scale when he was commenting on Obama's speech, specifically when talking about the values related to force-feeding the detainees at Guantanamo Bay. Stewart then commented that based on a forefounders' scale, everything did not seem right because the American forefounders never thought that the United States would ever have a black president. Accordingly, everything was possible- even if it was not right. Stewart then compared himself to Thomas Jefferson, the writer of the Declaration of Independence, who fought against slavery though he had slaves himself. It was possible that he was referring to the people having double standards which could make the evaluation of what they did really challenging.

Another conceptual metaphor was CITIZENS AS OBJECTS. In more than one instance, there was a constant reference to "ruining" people's lives because of profiling. The whole point was to show how people had double-standards. This was made clear in the episode when Wayne Allen Root, a conservative, believed that being profiled by the 
IRS, which targeted conservatives, or Tea Party members, was different from targeting Latinos, Arabs and Muslims, even if they had American citizenship. There was a clear reference that the IRS was ruining and destroying his life but not ruining "others' lives". To him, being profiled for religious and ethnic reasons was just a matter of inconvenience but was still deemed necessary to protect the rest of the Americans. Talking about the different levels of inconvenience helped, even though this segment was an act, shed light on how minorities were treated. The whole segment showed how a hypocrite Root was because he wanted his own benefit, but not that of others'.

Another conceptual metaphor was POLITICIANS AS NONLIVING OBJECTS. Jessica Williams, one of Stewart's reporters, interviewed Stephen Sandstrom, Utah State Representative, who changed his opinion about immigrants. Since politicians were known to lack empathy, it was never easy for them to change their political views. Sandstrom was known to be against immigrants but then changed his opinion when he listened to the story of a girl who lived her whole life in the States, but was still undocumented. Williams made fun of the situation by saying that he never knew he was prone to empathy because he thought he was emotionally immune. She was referring to all politicians who never seemed to listen to their own people i.e. those who voted for them. Williams then compared his situation to that of Rob Portman who changed his views on gay marriages after knowing that his own son was gay. Williams described changing one's views as a disease called "Portmannitis", from the name Portman. Thus, if a politician was meant to have feelings then he was immediately accused of being sick or abnormal, since the normal attitude was not to listen or have feelings.

\section{Ontological Metaphors}

Personification was made clear in GOVERNMENT AS A HYPOCRITE AND LIAR (13.6\%) and JOUNALISM AND PROSECUTION AS FREE HUMAN BEINGS (9\%). One example was 
when the Obama administration was accused of snooping on journalists, which made Obama talk about the necessity of having free press. Stewart also showed how the Obama administration made a promise to create a computerized veterans' health records system, which never took place. In these two examples, the American administration was portrayed as a human being who was snooping on others and who was capable of making a promise. Another example was given during the National Rifle Association's $142^{\text {nd }}$ annual meeting when Stewart said that at the heart of the NRA messages was that liberals should not use fear to convince people of the need of not carrying a gun; however, they should let the conservatives use fear to convince them of the necessity of carrying a gun, thus highlighting their hypocrisy.

Another example of personification was JOURNALISM AND PROSECUTION AS FREE HUMAN BEINGS. Journalism is believed to be characterized by freedom of expression all around the world. Stewart used the term free press to emphasize this concept because it was one of the main drawbacks of the Obama administration with so many correspondents being arrested for what did not seem to be a serious matter. Stewart also said that Obama was questioning if the overzealous prosecution of the war on terror and what happened at Guantanamo bay, with prisoners going on strike, was affecting Americans' souls. Obama was referring to the American values that had always been clear and how the government was always transparent about those values.

\section{Conclusion}

It is clear from the analysis that structural metaphors were more than ontological metaphors. Structural metaphors were of five kinds (77.3\%) and ontological metaphors were of two kinds only $(22.7 \%)$. The most common structural metaphors were POLITICS AS ART and GOVERNMENT AS A CORRUPT BUISNESS MODEL as they constituted $59 \%$ of all the metaphors employed. These metaphors reflected how politicians were always regarded as actors, whether good 
or bad, who wanted to reach their destinations. However, in so many cases, these politicians were not competent enough because they made so many wrong decisions which never really helped their countries. As for ontological metaphors, even though they only constituted $22.7 \%$, they showed how prosecution and journalism should always be regarded as free human beings. All of this shows that the use of some source domains like art, business and freedom could render a lot of the message clear and can encourage the citizens to see the reality of their presidents and politicians. 


\section{References}

Baym, G. (2005). The Daily Show: Discursive Integration and the Reinvention of Political

Journalism. Political Communication, 22, 259-276. DOI: $10.1080 / 10584600591006492$

Borčić, N., Kanižaj, I. \& Kršul, S. (2016). Conceptual Metaphor in Political Communication. Zbornik Sveučilišta u Dubrovniku, (3), 73-94. Retrieved June 14, 2020, from https://hrcak.srce.hr/169955

Brugman, B. \& Burgers, C. \& Vis, B. (2019). Metaphorical framing in political discourse through words vs. concepts: A meta-analysis. Language and Cognition. 10.1017/langcog.2019.5.

Charteris-Black, J. (2009). Metaphor and Gender in British Parliamentary Debates. In K. Ahrens (Ed.). Politics, Gender and Conceptual Metaphors, 139-165. Retrieved June 7, 2020, from https://link.springer.com/content/pdf/10.1057\%2F978023024523 5.pdf

Chen, C. (2014). A Diachronic Study of Political Metaphors and Their Social

Implications in Government Work Reports (1983-2013) in China. English Language and

Literature Studies, 4 (3), 71-76. Retrieved June 3, 2020, from http://dx.doi.org/10.5539/ells.v4n3p71

Cutbirth, J. H. (2011). Satire as journalism: "The Daily Show" and American politics at the

turn of the twenty-first century $[\mathrm{PhD}$ dissertation, Columbia University]. Retrieved

May 8, 2015, from

http://search.proquest.com/docview/868328376?pqorigsite $=$ summon\&accountid $=8423$ 
Gibbs, R. (2011). Evaluating Conceptual Metaphor Theory, Discourse Processes, 48

(8), 529-

562. DOI: $10.1080 / 0163853 X .2011 .606103$

Gray, J., Jones, J., \& Thompson, E. (Eds.). (2009). The state of satire, the satire of state. In

Satire TV: Politics and comedy in the post-network era, 3-36. New York: New York University Press (NYU Press). Retrieved on May 8, 2015 from http://www.ebrary.com

Kovecses, Z. (2010). Metaphor and Culture. Acta Universitatis Sapientiae, Philologica, 2 (2), 197-220. Retrieved June 6, 2020, from http://www.acta.sapientia.ro/acta-philo/C2-2/philo22-1.pdf

Lakoff, G., \& Johnson, M. (1980). Metaphors we live by. Chicago: University of Chicago Press.

Lemana, Y. C. \& Gatcho, A. R. (2019). Unveiling the microstructure elements of President Rodrigo Duterte's interviews: A political discourse analysis. International Journal of Language and Literary Studies, 1(3), 100-111. https://doi.org/10.36892/ijlls.v1i3.76

Lesz, B. (2011). To shape the world for the better: An analysis of metaphors in the speeches of Barack Obama [MA thesis, UNIVERSITETET I TROMSØ]. Retrieved June 6, 2020, from https://pdfs.semanticscholar.org/3bd4/2783404ecc52e89c07516da e56a02d39c2c7.pdf.

Mcglone, M. (2007). What Is the Explanatory Value of a Conceptual Metaphor? Language \& Communication, 27, 109-126. DOI; 10.1016/j.langcom.2006.02.016.

Ohl, J., Pfister, D.S., Nader, M., \& Griffin, D. (2013). Lakoff's theory of moral reasoning in Presidential campaign advertisements, 19522008. Communication Studies 64 (5): 488-507. doi: 10.1080/10510974.2013.832340 
Penninck, H. (2014). An analysis of metaphor used in political speeches responding to the financial crises of 1929 and 2008 [MA thesis, Universiteit Gent]. Retrieved June 6, 2020, from https://lib.ugent.be/fulltxt/RUG01/002/162/198/RUG01002162198_2014_0001_AC.pdf

Semino, E. \& Koller, V. (2009). Metaphor, politics and gender: A case study from Italy. In E.K. Ahrens (Ed.). Politics, Gender and Conceptual Metaphors. 36-61. Retrieved June 7, 2020, from https://link.springer.com/content/pdf/10.1057\%2F978023024523 5.pdf 